\title{
Lilac Cultivar Name Registration 1999
}

\author{
Freek Vrugtman ${ }^{1}$ \\ Royal Botanical Gardens, Box 399, Hamilton, Ontario L8N 3H8, Canada
}

\begin{abstract}
All correspondence concerned with additional information or plants or propagules of newly registered lilac cultivars should be directed to the registrants listed below, not to the Registrar.

Commencing with 1995 lilac registrations, standard portfolios are being established in accordance with Principle 3 and Articles 12, 22

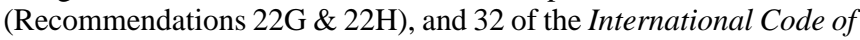
Nomenclature for Cultivated Plants-1995 (ICNCP-1995).

Previous registration lists of Syringa cultivar names appeared in AABGA Bulletin [13(4):105-110; 14(3):95; 15(3):71-72; 16(4):131132; 17(3):67-69; 18(3):87]; HortScience [23(3):458; 24(3):435$436 ; 25(6): 618 ; 26(5): 476-477 ; 29(9): 972 ; 31(3): 327-328 ; 32(4): 587-$ 588; 33(4):588-589; 34(4):600].

Syringa vulgaris L. 'Atheline Wilbur' was registered 26 Nov. 1999 by Charles E. Tubesing, Chief Horticulturist, The Holden Arboretum, 9500 Sperry Road, Kirtland, OH 02130, USA. The ortet (original plant) was originated, and selected prior to 1980 by the late John L. Fiala at Medina, Ohio, from progeny of the cross ('Rochester' ( 'Edward J. Gardner') ( 'Rochester'. The cultivar was named by Fiala in 1980 "to honor a lovely lady who cherished lilacs." The original descriptions appearing in Lilacs - Proceedings 9:8 [Jan. 1981], and on p. 102, 108, and 223, and with plate 22 in: Fiala, J. L., 1988, LilacsThe genus Syringa, Portland, Timber Press, are incomplete. The Holden Arboretum received plants from the originator in 1983, accessioned as HA\#83-366. Florets fully double, hose-in-hose, with three to five superimposed corollas. Lobes of the innermost corolla incompletely developed, one or more of these lobes being reduced and curled toward the center of the floret; zero to two stamens per floret, indicative of staminodes contributing to the doubleness. Flower buds Red-Purple Group 58A (Royal Horticultural Society Colour Chart, 1986 ed.). Interior of newly opened florets Violet-Blue Group 92D, and Red-Purple Group 75C on the reverse. Because the florets do not open all at once, an inflorescence containing unopened buds to fully open florets shows a combination of these colors. As the florets fade, the last colors listed become mixed with patches of White Group 155D. Fragrance light and pleasant. Introduced through The Holden Arboretum in 1993, and commercially available since 1995. A stan-
\end{abstract}

${ }^{\mathrm{I}}$ Contribution No. 94, Royal Botanical Gardens, Hamilton, Ontario, Canada. International Registrar, International Registration Authority for Cultivar Names in the Genus Syringa L. E-mail: <lilacreg@rbg.ca> dard portfolio has been opened at Royal Botanical Gardens Herbarium, Hamilton, Ontario, Canada.

The following two lilac cultivar names were registered 12 Dec. 1999 by Max Peterson, RR\#1, Box 273, Ogallala NE 69153, USA. The ortets (original plants) were originated, grown, selected, and named by Max Peterson at Meadowlark Hill Gardens. Standard portfolios have been opened at Royal Botanical Gardens Herbarium, Hamilton, Ontario, Canada.

Syringa vulgaris L. 'Beth'. Grown from open-pollinated seed; seed parent grown in 1978 from irradiated seed of unknown parentage. Seedlings flowered first in 1990; selection made in 1992; released to the nursery trade in 1997. Floriferous shrub of dense, bushy habit, slow growing, reaching $1.25 \mathrm{~m}$ after 8 years; suckering freely. Thyrses to 18 $\mathrm{cm}$ long and 20 to $23 \mathrm{~cm}$ across, of the C-12 type but thicker, as illustrated in Dvorak, J. Jr., 1978, A four year study at Lilac Park, The Morton Arboretum, etc., p. 7. Thyrses produced clear to the ground; florets numerous and clustered heavily toward the end of the stem. Florets double, triple hose-in-hose, 0.7 to $1.9 \mathrm{~cm}$ in diameter; tube long and narrow, usually exceeding $2.5 \mathrm{~cm}$. Corolla lobes of outer tier reflexed and acute; lobes of middle tier slightly reflexed and acute; inner tier lobes curved inward, forming a cup-shaped structure. Flower buds and florets white.

Syringa vulgaris L. 'Reva Ballreich'. Grown from open-pollinated seed of 'Carolyn Mae' in 1966. Seedlings flowered first in 1988; selection made in 1992; released to the nursery trade in 1997. Shrub of dense habit, reaching $2.5 \mathrm{~m}$; suckering freely. Thyrses to $21 \mathrm{~cm}$ long and $10 \mathrm{~cm}$ across, of the C-3 type as illustrated in Dvorak, J. Jr., 1978, A four year study at Lilac Park, The Morton Arboretum, etc., p. 6. Thyrses produced clear to the ground. Florets double, triple hose-inhose, 1.9 to $2.6 \mathrm{~cm}$ in diameter; florets of type 4-G, Dvorak 1978, p. 5. Corolla lobes of outer tier reflexed and acute; lobes of middle tier curved inward and acute; inner tier remains closed for about threequarters of the floret's life. Flower buds Red-Purple Group 70A (RHS Colour Chart, 1966), opening to Red-Purple 69D flushed white, with the corolla tubes remaining Red-Purple Group 70A; the inner corollatier remains Red-Purple Group 70A until it opens and turns RedPurple Group 69D; finally, the floret fades to off-white. The progression of opening and fading florets produces a bi-color effect. The blossoms of 'Reva Ballreich' are comparable to those of 'Julien Gérardin', but larger, more pinkish, and with the innermost petals recurved. 